\title{
Effects of dimethoate and neemarin insecticides on the biology of Pieris brassicae (Linn.) on cabbage
}

\author{
HADI HUSAIN KHAN*, M. SHAFIQ ANSARI, WAJID HASAN, SUMIT KUMAR CHAUHAN AND MOHD. \\ DANISH
}

Department of Plant Protection, Faculty of Agricultural Sciences, Aligarh Muslim University, ALIGARH (U.P.) INDIA

\section{ARITCLE INFO}

Received : 29.01 .2016

Accepted : 21.03.2016

\section{KEY WORDS :}

Dimethoate, Neemarin, Cabbage,

Survivorship, Expectancy
*Corresponding author:

Email: hhkhan.amu.786@gmail.com

\begin{abstract}
An attempts has been made to study the effects of insecticides i.e. 0.05 per cent aqueous solution of dimethoate and Neemarin, on the biology of Pieris brassicae (Linn.) at $25 \pm 1^{\circ} \mathrm{C}$ and $70 \pm 10$ per cent relative humidity through life table methods. Survivorship and Expectancy of the life was greatest in the beginning of the age and decreased gradually with the advancement of the age in the all treatment including control. The number of eggs was found less in deltamethrin (192 eggs/female/generation) as compared to neemarin (207 eggs/female/generation), and dimethoate (214 eggs/ female/generation) while it was found 281 eggs/female/generation in the control. The net reproductive rate (Ro) was also reduced with the treatment of the insecticide. Kvalues of $P$. brassicae was lowest on Neemarin treatment. The peak of $\mathrm{k}$-value was found on Pre-pupal stage followed by Ist instar stage. It showed that Pre-pupal stage was the most susceptible stage on all treatments and non treated control .
\end{abstract}

How to view point the article : Khan, Hadi Husain, Ansari, M. Shafiq, Hasan, Wajid, Chauhan, Sumit Kumar and Danish, Mohd. (2016). Effects of dimethoate and neemarin insecticides on the biology of Pieris brassicae (Linn.) on cabbage. Internat. J. Plant Protec., 9(1) : 283-291. 